Kong. Res. J. 1(1) : 73-77, 2014

Kongunadu Arts and Science College, Coimbatore

\title{
EVALUATION OF WOUND HEALING ACTIVITY OF METHANOLIC EXTRACT OF SMILAX WIGHTII (A. DC.) IN WISTAR ALBINO RATS.
}

\author{
Uma Maheswari, P*., Shalimol, A., Arumugasamy, K. and M.R. Udhaya Sankar \\ Department of Botany, Kongunadu Arts and Science College, Tamilnadu, 641029, India. \\ *E.mail : umascience@gmail.com
}

\section{ABSTRACT}

The present experimental study was designed to evaluate the wound healing activity of methanolic extract of Smilax wightii A. DC. on incision and excision wound models in Wistar albino rats. The parameters studied were wound breaking strength, wound contraction area, epithelialization period, granulation tissue wet, dry weight and hydroxyproline content in incision wound model, percentage of wound contraction and period of epithelialization in excision wound model. The rats were administered topically with $100 \mathrm{mg} / \mathrm{kg}$ b.wt. (low dosage), $200 \mathrm{mg} / \mathrm{kg}$ b.wt. (moderate dosage) and $500 \mathrm{mg} / \mathrm{kg}$ b.wt. (high dosage) of methanolic extract of Smilax wightii (MESW). The activity of the extract treated groups were compared with that of the control $1 \%$ Spirit. Framycetin sulphate $0.2 \% \mathrm{w} / \mathrm{w}$ was used as the standard drug. In incision wound model, there was a significant increase in the wound breaking strength in all the experimental groups treated with MESW than that of the control. Similarly, significant $(\mathrm{P}<0.001)$ decrease in wound contraction area and period of epithelialization were also observed in the test group animals treated with MESW and the standard drug treated groups when compared to that of the control. , a significant increase was observed in granulation tissue wet and dry weight and hydroxyproline content in the test groups treated with MESW compared to the control. In exicision wound model, there was a significant increase $(\mathrm{P}<0.01)$ in the percentage of wound contraction and decrease in period of epithelialization in the experimental groups treated with $200 \mathrm{mg} / \mathrm{kgb} . w t$. (moderate dosage) and $500 \mathrm{mg} / \mathrm{kgb} . w t$ (high dosage) of MESW. The extract treated groups showed significant improvement in all the wound healing parameters of incision, and excision wound models.

Keywords: Smilax wightii extract, wound healing, incision and excision wound models.

\section{INTRODUCTION}

The genus Smilax comprises more than 300 species which are distributed on temperate, tropic and subtropic zones worldwide (Fnaec, 2002). About 24 species of Smilax genus are found in India (Saldhana and Wilson, 1976, Ramaswamy, et al., 2001). In South India, the genus is represented by 4 species viz., Smilax zeylanica Linn., Smilax aspera Linn., Smilax perfoliata Roxb. and Smilax wightii A. DC.(Gamble, 2004). The rare endemic plant, Smilax wightii A.DC. is generally distributed in Shola forests at high altitudes in Nilgiri Biosphere Reserve, the Western Ghats, Southern India (Paulsamy et al., 2009). The roots of Smilax wightii A. DC. have been reported to cure dysentery, amoebiasis, veneral diseases, urinary complaints, fever, antifertility, anaemia, rheumatic-arthritis, veterinary amoebiasis and gastric complaints (Adhikari et al., 2010). Smilax rhizomes have different kinds of pharmacological behaviours such as antibacterial, antifungal, antioxidant and other activities (Ozoy et al., 2008).

Wounds are physical injuries which involve coagulation, inflammation, formation of granulation tissue, matrix formation, remodelling of connective tissue, collagenization and aquisation of wound strength (Suresh Reddy et al., 2002). The wound healing process consists of four steps. The first stage is the inflammatory stage which is directed at preventing further loss of blood by platelet accumulation at the site leading to coagulation those results to the formation of thrombus. The debridement stage occurs from the third to the sixth day after injury and involves the appearance of neutrophils to clear contaminating organisms. The proliferation or repair stage is characterized by endothelial budding in the nearby blood vessels forming new capillaries that penetrate and nourish the injured tissue. The maturation stage commences from tenth day to several months depending on wound severity during which the number of capillaries decreases and wound changes from pink or white (Thakare et al., 2011).

Some of the synthetic drugs currently used for the treatment of wounds are not only expensive but also cause problems such as allergy, drug resistance etc and this situation has forced scientists to seek alternative drugs (Sai and Babu, 1998). A large number of plants are used by tribal and folklore in many countries for the treatment of wounds and burns. These phytomedicine are not only cheap and affordable but are also safe. The presence of various 
life-sustaining constituents in plants has urged scientist to examine these medicinal plants with a view to determine potential wound healing properties (Nayak and Pinto Pereira, 2006).

A survey of literature revealed that no scientific study on the wound healing activity of this plant has been carried out. Hence the present study was undertaken to assess the wound healing activity of methanolic extract of Smilax wightii (MESW) on incision and excision wound models in Wistar albino rats.

\section{MATERIALS AND METHODS}

\subsection{Plant material}

The plant Smilax wightii was collected from Uthagamandalam, the Nilgiri Hills, Western Ghats, Southern India, Tamil Nadu. The plant was identified and authenticated by a plant taxonomist, $\mathrm{M}$. Murugesan, Scientist, SACON, Coimbatore.

\subsection{Preparation of methanolic extract}

$500 \mathrm{~g}$ of the whole plant powder of Smilax wightii was shade dried and used to extract with methanol by using soxhlet apparatus. This extract was stored at $4^{\circ} \mathrm{C}$ and used for further studies.

\subsection{Animals}

Wistar albino rats of either sex and of the same age weighing between 150 - $250 \mathrm{~g}$ were used for the study. They were individually housed, maintained in clean polypropylene cages and fed with commercially pelleted rat chow (M/s Hindustan Lever Ltd. Mumbai) and Water ad libitum. The experimental protocol was subjected to the scrutiny of Institutional Animal Ethical Committee for experimental clearance (Reg No. 659/02/a/ CPCSEA).

\subsection{Toxicity studies}

The acute toxicity studies were carried out in adult male Wistar Albino rats weighing 180-250g. The animals were fasted overnight and $100-1000$ $\mathrm{mg} / \mathrm{kgb} . \mathrm{wt}$ of the test extract was given to various groups containing 6 animals in each group. The treated animals were monitored for 14 days for their behaviour, general health and mortality.

\subsection{Experiment}

The surgical interventions in incision and excision wound models were carried out under sterile conditions using ketamine anaesthesia (120mg/kgb.wt). The experimental animals were divided in to five groups of six animals in each group and received the following treatments. The first group were treated with $1 \%$ spirit topically and considered as untreated control. The second group were treated with $100 \mathrm{mg} / \mathrm{kgb} . w \mathrm{t}$ (low dosage) of MESW, the third group with $200 \mathrm{mg} / \mathrm{kgb} . w \mathrm{t}$ (moderate dosage) of MESW, the fourth group with $500 \mathrm{mg} / \mathrm{kg}$ b.wt(high dosage) of MESW and the fifth group were treated with $0.2 \% \mathrm{w} / \mathrm{w}$ Framycetin Sulphate (FSC) topically (standard drug). The MESW was applied on the wound for the test groups from the first day till the day of healing. The level of dosage was $2 \mathrm{ml}$ for all the three test groups.

\subsection{Incision wound}

The rats were anaesthetized prior to and during creation of the wound. The dorsal fur of the animals was shaved with an electric clipper. A longitudinal paravertebral incision, six centimeters in length was made through the skin and cutaneous muscle on the back (Ehrlich and Hunt, 1968). After the incision, surgical sutures were applied to the parted skin at intervals of one centimetre. The wounds were left undressed. The sutures were removed on the 8th post wound day and the treatment was continued. The wound-breaking strength was measured on the 10th day by the method of (Lee, 1968).

\subsection{Determination of wound breaking strength}

The anesthetized animal was secured to the table, and a line was drawn on either side of the wound $3 \mathrm{~mm}$ away from the line. This line was gripped using forceps one at each end opposite to each other. One of the forceps was supported firmly, whereas the other was connected to a freely suspended light weight metal plate. Weight was added slowly and the gradual increase in weight, pulling apart the wounded edges. As the wound just opened up, addition of weight was stopped and the weights added was noted as a measure of breaking strength in grams. Three readings were recorded for a given incision wound, and the procedure was repeated on the contra lateral wound. The mean reading for the group was taken as an individual value of breaking strength. The mean value gives the breaking strength for a given group.

\subsection{Determination of granulation tissue dry weight and wet weight}

In the healed tissues excised from incision wound model rats, the wet weight of the granulation tissue was noted. These granulation tissues were dried at $60^{\circ} \mathrm{C}$ for 12 hours, and weighed, and the dry weight was recorded. To the dried tissue added $5 \mathrm{ml}$ $6 \mathrm{~N} \mathrm{HCl}$ and kept at $110^{\circ} \mathrm{C}$ for 24 hours. The neutralized acid hydrolysate of the dry tissue was used for the determination of hydroxyproline (Neuman and Logan, 1950). 


\subsection{Estimation of Hydroxyproline}

Hydroxyproline present in the acid hydrolysate of granulation tissue oxidized by sodium peroxide in the presence of copper sulfate, when complexed with para-dimethylaminobenzaldehyde, develops a pink color that was measured at $540 \mathrm{~nm}$ using colorimetry.

\subsection{Excision wound model}

Animals were anaesthetized prior to and during creation of the wounds. The rats were inflicted with excision wounds as described by (Morton and Malon,1972). The dorsal fur of the animals was shaved with an electric clipper and the anticipated area of the wound to be created was outlined on the back of the animals with methylene blue using a circular stainless steel stencil. A full thickness of the excision wound of circular area $500 \mathrm{~mm}^{2}$ and $0.2 \mathrm{~cm}$ depth was created along the markings using toothed forceps, a surgical blade or pointed scissors. The entire wound was left open (Diwan and Tilloo,1982). The wound closure rate was assessed by tracing the wound on days $2,4,6,8$, 10,12 and 14 post-wounding using transparency papers and a permanent marker. The wound areas recorded were measured using a graph paper. Number of days required for falling of eschar without any residual raw wound gave the period of epithelialization.

\subsection{Statistical analysis}

The data is expressed as mean \pm SEM and subjected to one way ANOVA and the level of significance was set at $\mathrm{p}<0.05$.

\section{RESULTS AND DISCUSSION}

No sign of toxicity was noticed on the behaviour and general health of the animals when exposed to the extract at a dosage of 100$1000 \mathrm{mg} / \mathrm{kgb} . w t$. No deaths were also observed.

The wound contraction area and the period of epithelialization were observed at an interval of four days till the sixteenth day of wound healing. A rapid decrease in both the parameters were observed in the experimental groups treated with (MESW) and also in framycetin sulphate treated groups when compared to that of the control group in incision wound model (Table-2).

The granulation tissue wet and dry weight and the hydroxyproline content showed significant $(\mathrm{P}<0.01)$ increase in the extract treated groups when compared to the control. (Table-3). The increase in dry granulation tissue weight in the test group animals suggests higher protein content. The methanolic extract of Smilax wightii demonstrated a significant increase in the hydroxyproline content of the granulation tissue indicating increased collagen turnover. Collagen, the major component which strengthens and supports extra cellular tissue is composed of the amino acid, hydroxyproline, which has been used as a biochemical marker for tissue collagen (Kumar et al., 2006).

The wound contraction was assessed at an interval of two days till the fourteenth day of wound healing. It was observed that the percentage of wound contraction increased and the epithelialization period decreased significantly in excision wound model with the application of MESW as compared to the control group. The standard drug framycetin sulphate also showed profound activity in the percentage of wound contraction in excision wound model rats (Table-4). Preliminary phytochemical screening revealed the presence of tannins, alkaloids, flavonoids, terpenoids, phenols and tannins in Smilax wightii. Flavonoids have been documented to possess potent antioxidant and free radical scavenging effect, which is believed to be one of the most important components of wound healing (Devipriya and Shyamladevi, 1999).

\section{CONCLUSION}

The results of the present study has led to the conclusion that the methanolic extract of Smilax wightii has exhibited prominent wound healing activity in incision and excision wound models with significant results in all the parameters studied.

\section{REFERENCES}

Adhikari, B.S., M.M. Babu, P.L. Saklani and G.S Rawat, (2010). Medicinal Plants Diversity and their Conservation Status in Wildlife Institute of India (WII) Campus, Dehradun. Ethnobotanical Leaflets. 14: 46-83.

Devipriya, S. and C.S. Shyamladevi. (1999). Protective effect of quercetin in cisplatin induced cell injury in the kidney, Indian $J$ Pharmacol. 13: 422.

Diwan, P.V., L.D. Tilloo and D.R. Kulkarni. (1982). Influence of Tridax procumbens on wound healing. Ind J Med Res. 75: 460-464.

Ehrlich, H.P. and T.K Hunt. (1968). Effect of cortisone and vitamin A on wound healing, Ann Surg. 167: 324-328.

Fnaec, (2002). Flora of North America editorial committee.Flora of North America North of Mexico. 26: 14-46. 
Gamble JS. (2004). Flora of the Presidency of Madras. Dehradun: Bishen Singh, Mahendra Pal Singh, eds. 1518.

Kumar. R., S.S. Katoch and S.Sharma, (2006) . $\beta$ Adrenoceptor aganist treatment reverses denervation atrophy with augmentation of collagen proliferation in denervated mice gastrocnemius muscle. Indian J Exp Biol. 44(5): 371-376.

Lee, K.H. (1968). Studies on mechanism of action of salicylates II Retardation of wound healing by aspirin. J. Pharm. Sci. 57: 1042-1043.

Morton, J.J.P. and M.H. Malone. (1972) . Evaluation of vulnerary activity by an open wound procedure in rats. Arch. Int. Pharmacodyn. 196:117-126.

Nayak, B.S. and L.M. Pinto Pereira. (2006)."Catharanthus roseus flower extract has wound- healing activity in Sprague Dawley rats," BMC Complementary and Alternative Medicine. 6: 41.

Neuman, R.E. and M.A. Logan. (1950). The determination of hydroxyproline, J. Biol. Chem, 184(1): 299-306.
Ozsoy, N., A. Can, R.Yanardag and N. Akev. ( 2008). Antioxidant activity of Smilax excelsa L. leaf extracts. Food .Chem. 110: 571-583. 346.

Paulsamy, S., K.K.Vijayakumar, Bong-Seop Kil and P. Senthilkumar. (2009). Status of the RedListed Plant Species Smilax Wightii A. DC. In Nilgiri Biosphere Reserve, the Western Ghats, Indian. J. Ecology and Field Biology. 32: 249.

Ramaswamy, S.N., M. Radhakrishna Rao, and Govindappa, (2001). Flora of Shimoga district Karnataka, Mysore: Prasaranga, 619.

Sai, K.P. and M. Babu. (1998) Burns. 24: 387.

Saldhana, C.J. and D.H. Wilson. (1976). Flora of Hassan district of Karnataka, New Delhi: Amerind Pub Co Pvt Ltd. 804.

Suresh Reddy, J., P.R. Rao and M.S. Reddy. (2002).Wound healing effects of Heliotropium indicum, plumbago zeylanicum and Acalypha indica in rats. J. Ethnopharmacol. 79: 249.

Thakare, V.M., R.Y. Chaudhari and V.R. Patil, (2011). International Journal of hytomedicine. 3: 325.

Table 1. Effect of methanolic extract of Smilax wightii (MESW) on wound breaking strength in incision wound model.

\begin{tabular}{|c|c|c|c|c|c|}
\hline \multicolumn{3}{|c|}{ Groups (n) } & & \multicolumn{2}{|c|}{ Wound breaking strength(g) } \\
\hline \multicolumn{4}{|c|}{ Control - I } & \multicolumn{2}{|c|}{$318.26 \pm 4.18$} \\
\hline \multicolumn{4}{|c|}{ MESW-100mg/kg (low) - II } & \multicolumn{2}{|c|}{$431.16 \pm 4.84^{* *}$} \\
\hline \multicolumn{4}{|c|}{ MESW-200mg/kg - (moderate) - III } & \multicolumn{2}{|c|}{$482.16 \pm 3.93$ ** } \\
\hline \multicolumn{4}{|c|}{ MESW-500mg/kg (high) - IV } & \multicolumn{2}{|c|}{$514.1 \pm 3.84^{* * *}$} \\
\hline \multicolumn{4}{|c|}{ Standard drug (FSC) - V } & \multicolumn{2}{|c|}{$365.16 \pm 3.54$} \\
\hline \multicolumn{6}{|c|}{${ }^{*} \mathrm{P}<0.05,{ }^{* *} \mathrm{P}<0.01,{ }^{* * *} \mathrm{P}<0.001$, compared to control vs drug treated groups values are mean \pm S.E.M. $(\mathrm{n}=6)$} \\
\hline \multirow{2}{*}{\multicolumn{6}{|c|}{$\begin{array}{l}\text { In incision wound model, the extract treated animal (group II, IIIand IV) showed significant improvement in wound breaking strength } \\
\text { when compared to the control group (Table-1). } \\
\text { Table } 2 \text {. Effect of methanolic extract of Smilax wightii (MESW) on incision wound model. mean } \pm \text { SE } \\
\text { wound contraction area }\left(\mathbf{m m}^{\mathbf{2}} \text { ) }\right.\end{array}$}} \\
\hline & & & & & \\
\hline $\begin{array}{l}\text { Groups } \\
\text { (n) }\end{array}$ & 4th day & 8th day & 12th day & 16th day & $\begin{array}{l}\text { Epithelization } \\
\text { period }\end{array}$ \\
\hline Group I & $381.16 \pm 1.48$ & $361.16 \pm 2.91$ & $210.16 \pm 2.93$ & $138.13 \pm 2.54$ & $26.16 \pm 3.13$ \\
\hline Group II & $284.16 \pm 2.16$ & $232.13 \pm 1.93$ & $156.84 \pm 2.06^{* *}$ & $30.16 \pm 1.22^{* * *}$ & $17.84 \pm 0.54^{* * *}$ \\
\hline Group III & $230.16 \pm 1.84$ & $176.84 \pm 2.04^{*}$ & $76.16 \pm 0.93^{* * *}$ & $22.15 \pm 1.16^{* * *}$ & $16.34 \pm 0.84^{* * *}$ \\
\hline Group IV & $216.84 \pm 3.16$ & $184.92 \pm 3.10^{* *}$ & $31.18 \pm 0.93^{* * *}$ & $1.16 \pm 0.09 * * *$ & $12.28 \pm 0.85^{* * *}$ \\
\hline Group V & $211.16 \pm 3.11$ & $152.84 \pm 1.93^{* * *}$ & $54.13 \pm 0.18^{* * *}$ & $08.16 \pm 0.34^{* * *}$ & $11.65 \pm 1.13^{* * *}$ \\
\hline
\end{tabular}

${ }^{*} \mathrm{P}<0.05,{ }^{* *} \mathrm{P}<0.01,{ }^{* * *} \mathrm{P}<0.001$, compared to control vs drug treated groups values are mean \pm S.E.M. $(\mathrm{n}=6)$ 
Table 3. Effect of methanolic extract of Smilax wightii (MESW) on granulation tissue wet, dry weight and hydroxyproline content in incision wound model.

\begin{tabular}{|c|c|c|c|}
\hline Groups (n) & $\begin{array}{c}\text { Granulation tissue wet } \\
\text { weight (mg) }\end{array}$ & $\begin{array}{c}\text { Granulation tissue dry } \\
\text { weight (mg) }\end{array}$ & $\begin{array}{l}\text { Hydroxyproline } \\
\text { (mg/tissue) }\end{array}$ \\
\hline Control - I & $82.6 \pm 2.16$ & $12.5 \pm 0.91$ & $32.4 \pm 1.90$ \\
\hline MESW-100mg/kg (low) - II & $131.58 \pm 1.93^{* *}$ & $21.13 \pm 0.16^{* *}$ & $80.2 \pm 4.16^{*}$ \\
\hline $\begin{array}{l}\text { MESW }-200 \mathrm{mg} / \mathrm{kg}- \\
\text { (moderate) - III }\end{array}$ & $172.46 \pm 3.84^{* *}$ & $22.5 \pm 0.34$ ** & $85.84 \pm 2.27^{* *}$ \\
\hline MESW-500mg/kg (high) - IV & $188.54 \pm 4.20^{* *}$ & $24.16 \pm 0.93^{* *}$ & $95.96 \pm 2.55^{* *}$ \\
\hline Standard drug (FSC) $-V$ & $124.16 \pm 3.40^{*}$ & $18.4 \pm 0.16^{* *}$ & $92.16 \pm 2.88^{*}$ \\
\hline
\end{tabular}

Table 4. Effect of methanolic extract of Smilax wightii (MESW) on percentage of wound contraction in excision wound model.

\begin{tabular}{|c|c|c|c|c|c|c|c|c|}
\hline \multirow{2}{*}{ Groups } & \multirow{2}{*}{$\begin{array}{c}\text { Epithelization } \\
\text { Period } \\
\text { (days) }\end{array}$} & \multicolumn{7}{|c|}{ Excision Wound model\% of Wound contraction in different days } \\
\hline & & 2 & 4 & 6 & 8 & 10 & 12 & 14 \\
\hline Group I & $20.16 \pm 0.28$ & $16.31 \pm 0.27$ & $28.16 \pm 0.16$ & $34.65 \pm 0.78$ & $41.16 \pm 0.75$ & $55.16 \pm 0.93$ & $63.16 \pm 0.91$ & $69.54 \pm 1.16$ \\
\hline Group II & $13.42 \pm 0.84^{* *}$ & $21.34 \pm 1.06$ & $43.91 \pm 0.84^{*}$ & $59.16 \pm 0.93$ & $76.28 \pm 0.16^{*}$ & $84.24 \pm 0.16^{* *}$ & $87.16 \pm 1.84$ & $93.16 \pm 0.84^{* *}$ \\
\hline Group III & $15.13 \pm 0.92^{* *}$ & $29.16 \pm 0.84^{*}$ & $58.31 \pm 0.96^{*}$ & $68.36 \pm 0.91^{*}$ & $82.68 \pm 1.16^{* *}$ & $96.1 \pm 1.34^{*}$ & $98.54 \pm 0.91^{* *}$ & $99.13 \pm 1.06^{* *}$ \\
\hline Group IV & $17.83 \pm 0.28^{*}$ & $30.84 \pm 0.91 *$ & $62.84 \pm 0.84 *$ & $75.16 \pm 10.6^{*}$ & $89.16 \pm 0.28^{*}$ & $90.33 \pm 1.81 *$ & $96.84 \pm 0.56^{* *}$ & $98.84 \pm 0.16^{* *}$ \\
\hline Group V & $16.33 \pm 0.27$ & $24.13 \pm 0.18^{*}$ & $60.33 \pm 0.16^{*}$ & $69.26 \pm 1.06^{*}$ & $85.16 \pm 0.18^{*}$ & $91.36 \pm 0.91 *$ & $94.32 \pm 0.84^{* *}$ & $97.29 \pm 1.04^{* *}$ \\
\hline
\end{tabular}

